\title{
PENGARUH SOFTWARE GEOGEBRA TERHADAP HASIL BELAJAR PESERTA DIDIK PADA MATERI FUNGSI KUADRAT KELAS X MA SARJI AR-RASYID SITUBONDO
}

\author{
Ika Irmawati ${ }^{1}$, Lisma Dian Kartika Sari ${ }^{2}$, Tri Astindari ${ }^{3}$ \\ ${ }^{1,2,3}$ STKIP PGRI Situbondo, Indonesia \\ ikairmawati6@gmail.com
}

\begin{abstract}
The purpose of this study was to determine the effect of using Geogebra software on student learning outcomes on the quadratic function material in Class X MA Sarji Ar-Rasyid Situbondo. The research method used a quasi-experimental research design with data collection techniques used, namely pretest and posttest. The data analysis technique used the normality test, homogeneity test, and t-test. From the t-test analysis, results obtained sig $0.263>$ a 0.05 . So it can be concluded that there is no significant effect between students taught by learning GeoGebra software with conventional learning. This result is due to students' low ability and experience in using Geogebra software for mathematics learning.
\end{abstract}

Keywords: Geogebra Software, Learning Outcomes, and Quadratic Functions

\begin{abstract}
Abstrak: Tujuan penelitian ini adalah untuk mengetahui Pengaruh pemanfaatan software Geogebra terhadap hasil belajar peserta didik pada materi fungsi kuadrat di Kelas X MA Sarji Ar-Rasyid Situbondo. Metode penelitian menggunakan rancangan penelitian eksperimen semu dengan teknik pengumpulan data yang digunakan yaitu pretest dan posttest. Teknik analisis data menggunakan uji normalitas, uji homogenitas, dan uji t. Dari hasil analisis uji-t yang telah dilakukan, diperoleh hasil sig 0,263> a 0,05. Sehingga dapat disimpulkan bahwa tidak terdapat pengaruh yang signifikan antara peserta didik yang diajar dengan pembelajaran software geogebra dengan pembelajaran konvensional. Hal ini disebabkan karena rendahnya kemampuan dan pengalaman siswa dalam pemanfaatan software Geogebra untuk pembelajaran matematika.
\end{abstract}

Kata Kunci: Software Geogebra, Hasil Belajar, dan Fungsi Kuadrat

\section{PENDAHULUAN}

Matematika adalah ilmu yang mempelajari tentang suatu pelajaran yang tersusun secara beraturan, logis, dan berjenjang dari yang paling mudah sampai yang paling rumit. Salah satu pelajaran di sekolah yang dapat mengajak peserta didik untuk mengasah kemampuannya adalah matematika, seperti pendapat Yulianti et al (dalam Fitriana et al, 2017). Mata pelajaran matematika itu sendiri perlu diberikan kepada peserta didik tujuannya untuk membekali peserta didik agar mampu berpikir kritis, sistematis, analisis, dan mempunyai kemampuan berpikir logis. Matematika juga merupakan salah satu mata pelajaran yang sangat penting untuk dikuasai oleh peserta didik (Helmiah, 2018). 
Salah satu cabang matematika mempunyai banyak permasalahanpermasalahan yang membutuhkan suatu pemecahan masalah yaitu program linier. Berdasarkan pengalaman mengajar, Program linier ini merupakan konsep dalam matematika yang dianggap sulit bagi peserta didik misalnya mengenai materi fungsi kuadrat. Peserta didik mengalami kesulitan dalam menggambar grafik dalam fungsi kuadrat, menentukan arah pada grafik, dan peserta didik mengalami kesulitan menemukan soal fungsi kuadrat pada grafik ketika sudah disediakan. Hal itu terjadi karena kurangnya kemandirian peserta didik untuk mencoba menyelesaikan soal atau permasalahan. Kurangnya kemandirian ini menyebabkan keterampilan proses peserta didik seperti kemampuan menghitung dan menggambar grafik. Hal ini sejalan dengan pendapat Effendi (dalam Fitriana et al, 2017) yang menyatakan bahwa nilai rata-rata peserta didik masih dibawah kriteria karena peserta didik hanya menggunakan model atau strategi pembelajaran yang monoton.

Berdasarkan kesulitan yang dialami peserta didik, salah satucara untuk mengatasinya ialah dengan menggunakan strategi pembelajaran melalui media pembelajaran yang dapat menarik peserta didik dan tujuannya untuk meningkatkan pemahaman peserta didik. Media pembelajaran pada umumnya berfungsi dapat meningkatkan hasil belajar peserta didik karena hasil belajar juga merupakan salah satu indikator dalam keberhasilan belajar. Hasil belajar juga dapat menggambarkan kemampuan-kemampuan yang telah dicapai peserta didik dalam proses pembelajaran berlangsung. Salah satu program komputer yang dapat dimanfaatkan sebagai media pembelajaran matematika adalah program geogebra. GeoGebra adalah program komputer (software) untuk membelajarkan matematika khususnya geometri dan aljabar pendapat Hohenwarter (dalam Arbain et al, 2015). Dengan beragam fasilitas yang dimiliki, geogebra dapat dimanfaatkan sebagai media pembelajaran matematika untuk mendemonstrasikan atau memvisualisasikan konsep-konsep matematis serta sebagai alat bantu untuk mengkonstruksi konsepkonsep matematis.

\section{METODE}

Penelitian ini menggunakan metode Purposive Sampling Area yaitu teknik pengambilan daerah/lokasi penelitian ditentukan secara sengaja (Sugiyono, 2016:83). Penelitian ini dilaksanakan di MA Sarji Ar-Rasyid. Populasi dalam 
penelitian ini adalah seluruh peserta didik Kelas X MA Sarji Ar-Rasyid dalam pelajaran matematika semester genap tahun pelajaran 2019/2020. Jumlah responden dalam penelitian ini adalah 40 responden. Sampel penelitian ini terdiri dari dua kelas yaitu kelas kontrol dan eksperimen. Teknik pengumpulan data pada penelitian ini menggunakan 4 teknik yaitu, tes, dokumentasi, observasi, dan wawancara. Analisis data yang digunakan adalah uji normalitas, uji homogenitas, uji hipotesis, dan uji t.

\section{HASIL DAN PEMBAHASAN}

\section{Hasil}

\section{Uji Normalitas}

Nilai Sig. 0,057 > a 0,05 untuk data pretest kelas eksperimen, sedangkan kelas kontrol nilai Sig. 0,627 > a 0,05. Hal ini menunjukkan hipotesis nol untuk setiap kelas diterima. Sehingga dapat disimpulkan bahwa kedua kelas diperoleh dari data yang terdistribusi normal. Nilai Sig. 0,234> a 0,05 untuk data posttest kelas eksperimen, sedangkan kelas kontrol nilai Sig. 0,232 > a 0,05. Hal ini menunjukkan hipotesis nol untuk setiap kelas diterima. Sehingga dapat disimpulkan bahwa kedua kelas diperoleh dari data yang terdistribusi normal.

\section{Uji Homogenitas}

Nilai Sig. 0,154 > a 0,05. Maka $\mathrm{H}_{\mathrm{a}}$ ditolak $\mathrm{H}_{0}$ diterima, artinya data nilai pretest kelas eksperimen dengan kelas kontrol memiliki varians yang sama. Sedangkan nilai Sig. 0,263> a 0,05. Maka $\mathrm{H}_{\mathrm{a}}$ ditolak $\mathrm{H}_{0}$ diterima, artinya data nilai posttest kelas eksperimen dengan kelas kontrol memiliki varians yang sama.

\section{Uji-t (Independent Sampel T-Test)}

Tabel 1. Output SPSS 18.0 Hasil Uji Independent Sampel T-test Data Pretest Independent Samples Test

\begin{tabular}{|c|c|c|c|c|c|c|c|c|c|c|}
\hline & \multicolumn{2}{|c|}{$\begin{array}{c}\text { Levene's Test for } \\
\text { Equality of } \\
\text { Variances } \\
\end{array}$} & \multicolumn{7}{|c|}{ t-test for Equality of Means } \\
\hline & & \multirow[b]{2}{*}{$\mathrm{F}$} & \multirow[b]{2}{*}{ Sig. } & \multirow[b]{2}{*}{$\mathrm{T}$} & \multirow[b]{2}{*}{ Df } & \multirow{2}{*}{$\begin{array}{l}\text { Sig. } \\
(2- \\
\text { tailed })\end{array}$} & \multirow{2}{*}{$\begin{array}{l}\text { Mean } \\
\text { Differe } \\
\text { nce }\end{array}$} & \multirow{2}{*}{$\begin{array}{l}\text { Std. } \\
\text { Error } \\
\text { Differen } \\
\text { ce }\end{array}$} & \multicolumn{2}{|c|}{$\begin{array}{l}95 \% \text { Confidence } \\
\text { Interval of the } \\
\text { Difference }\end{array}$} \\
\hline & & & & & & & & & Lower & Upper \\
\hline $\begin{array}{l}\text { Hasil } \\
\text { Belajar }\end{array}$ & $\begin{array}{l}\text { Equal } \\
\text { variances } \\
\text { assumed } \\
\text { Equal } \\
\text { variances } \\
\text { not } \\
\text { assumed }\end{array}$ & 2,118 &, 154 & ,404 & 36,348 & ,688 & ,85000 & 2,10247 & $-3,40624$ & $\begin{array}{r}5,1062 \\
4 \\
5,1126 \\
0\end{array}$ \\
\hline
\end{tabular}


Dilihat dari Tabel 3.1 Nilai Sig 0,154 dengan taraf signifikan 5\%. Nilai Sig $0,154>$ a 0,05 dan hasil perhitungan menunjukkan bahwa $t_{\text {hitung }} 0,405<t_{\text {tabel }} 1,724$ maka $\mathrm{H}_{0}$ diterima ( $\mathrm{H}_{\mathrm{a}}$ ditolak), sehingga dapat disimpulkan bahwa tidak terdapat perbedaan kemampuan awal kelas eksperimen dengan kelas kontrol atau dapat dikatakan kedua kelas mempunyai kemampuan awal yang sama.

Tabel 2. Output SPSS 18.0 Hasil Uji Independent Sampel T-test Data Posttest

Independent Samples Test

\begin{tabular}{|c|c|c|c|c|c|c|c|c|c|c|}
\hline & \multicolumn{2}{|c|}{$\begin{array}{c}\text { Levene's Test } \\
\text { for Equality of } \\
\text { Variances } \\
\end{array}$} & \multicolumn{7}{|c|}{ t-test for Equality of Means } \\
\hline & & \multirow[b]{2}{*}{$\mathrm{F}$} & \multirow[b]{2}{*}{ Sig. } & \multirow[b]{2}{*}{$\mathrm{T}$} & \multirow[b]{2}{*}{ Df } & \multirow{2}{*}{$\begin{array}{l}\text { Sig. } \\
(2- \\
\text { tailed })\end{array}$} & \multirow{2}{*}{$\begin{array}{c}\text { Mean } \\
\text { Differe } \\
\text { nce }\end{array}$} & \multirow{2}{*}{$\begin{array}{c}\text { Std. } \\
\text { Error } \\
\text { Differen } \\
\text { ce }\end{array}$} & \multicolumn{2}{|c|}{$\begin{array}{l}95 \% \text { Confidence } \\
\text { Interval of the } \\
\text { Difference }\end{array}$} \\
\hline & & & & & & & & & Lower & Upper \\
\hline $\begin{array}{l}\text { Hasil } \\
\text { Belajar }\end{array}$ & $\begin{array}{l}\text { Equal } \\
\text { variances } \\
\text { assumed } \\
\text { Equal } \\
\text { variances not } \\
\text { assumed }\end{array}$ & 1,291 & ,263 & ,343 & 36,696 & ,734 & 65000 & 1,89719 & $-3,19067$ & $\begin{array}{r}4,4906 \\
7 \\
4,4951 \\
5\end{array}$ \\
\hline
\end{tabular}

Dilihat dari Tabel 3.2 Nilai Sig 0,263 dengan taraf signifikan 5\%. Nilai Sig $0,263>$ a 0,05 dan hasil perhitungan menunjukkan bahwa thitung $0,343<t_{\text {tabel }} 1,724$ maka $\mathrm{H}_{0}$ diterima $\left(\mathrm{H}_{\mathrm{a}}\right.$ ditolak), sehingga dapat disimpulkan bahwa tidak terdapat perbedaan kemampuan kelas eksperimen dengan kelas kontrol atau dapat dikatakan kedua kelas mempunyai kemampuan yang sama pada materi fungsi kuadrat.

\section{Pembahasan}

Berdasarkan analisis dan penyajian data di atas dapat diketahui bahwa ratarata nilai kelas eksperimen dengan kelas kontrol pada hasil belajar posttes tidak jauh berbeda atau bisa dikatakan tidak memiliki perbedaan. Kedua kelas ini tidak memiliki perbedaan hasil belajar software geogebra dan tanpa software geogebra dengan nilai Sig 0,263> a 0,05 dan hasil perhitungan menunjukkan bahwa $t_{\text {hitung }}$ $0,343<\mathrm{t}_{\text {tabel }} 1,724$. Dengan demikian dapat disimpulkan bahwa tidak ada pengaruh software geogebra terhadap hasil belajar peserta didik pada materi fungsi kuadrat kelas X MA Sarji Ar-Rasyid semester genap tahun pelajaran 2019/2020. Tidak terdapat perbedaan rata-rata nilai posttes peserta didik yang diajar menggunakan software geogebra dan tanpa menggunakan software geogebra hal ini disebabkan karena, 1) Kurangnya kemampuaan kognitif yang dimiliki peserta didik terhadap 
materi fungsi kuadrat, 2) Kurangnya pengetahuan peserta didik terhadap software Geogebra. software geogebra ini merupakan hal baru bagi peserta didik kelas $\mathrm{X}$ MA Sarji Ar-Rasyid, sehingga mereka belum mengetahui dan memahami secara mendalam tentang software geogebra ini, 3) Kurangnya sarana prasarana di sekolah untuk mendukung penggunaan software geogebra seperti harus menggunakan komputer/laptop, 4) Dengan kondisi pada saat ini yaitu pandemi Covid-19 pembelajaran di kelas dibatasi waktunya, sehingga pengetahuan yang bisa diserap peserta didik juga terbatas.

\section{SIMPULAN}

Berdasarkan hasil data penelitian dapat disimpulkan bahwa tidak ada pengaruh software geogebra terhadap hasil belajar peserta didik pada materi fungsi kuadrat kelas X MA. Sarji Ar-Rasyid semester genap tahun pelajaran 2019/2020.

\section{DAFTAR RUJUKAN}

Arbain, Nazihatulhasanah, Shukor, \& A, N. (2015). The Effect of GeoGebra on Students Achievment. Kuala Lumpur: Global Conference on Business \& Social Science.

Fitriana, Mawarsari, V. D., \& Aziz, A. (2017). Implementasi Model Pembelajaran Kooperatif Tipe Pair Check Berbatuan Doftwere Geo Gebra Terhadap Kemampuan Pemahaman Konsep Matematis Materi Trigonometri Kelas X. Isbn : 978-662-61599-6-0, 124-132.

Sugiyono. (2016). Metode Penelitian Kuantitatif, Kualitatif, dan R\&D. Kota Bandung: Penerbit Alfabeta.

Helmiah, Lilis. (2018). Pengaruh Pemberian Kuis pada awal Pembelajaran melalui Model Pembelajaran Langsung terhadap Hasil Belajar Siswa pada Mata Pelajaran Matematika Kelas VIII Semester Genap di MTSN 1 Situbondo Tahun Pelajaran 2017/2018. Skripsi Sarjana Pendidikan. STKIP PGRI SITUBONDO.

Widodo. (2017). Metodologi Penelitian Populer dan Praktis. Penerbit PT Rajagrafindo Persada, Depok.

Hikmawati, Fenti. (2017). Metodologi Penelitian. Penerbit PT Rajagrafindo Persada, Depok. 